ISSN 1392-3196 / e-ISSN 2335-8947

Zemdirbyste-Agriculture, vol. 100, No. 3 (2013), p. 325-334

DOI $10.13080 /$ z-a.2013.100.042

\title{
Recent advances in molecular tool development for drought tolerance breeding in cereal crops: a review
}

\author{
Mueen Alam KHAN, Muhammad IQBAL, Muhammad AKRAM, \\ Maqshoof AHMAD, Muhamad Waqar HASSAN, Moazzam JAMIL \\ College of Agriculture and Environmental Science, The Islamia University of Bahawalpur \\ 63100 Pakistan \\ E-mail: mueen_1981@yahoo.com
}

\begin{abstract}
Drought stress is one of the major yield constraints for cereal crops. Traditionally, for developing drought tolerant cultivars, selection either direct or indirect is practiced. Although this approach is effective, yet time consuming and labour intensive. Identification of drought related quantitative trait loci (QTLs) coupled with marker assisted selection has shown some positive results. Transgenic and "omics" technologies promise to make progress in breeding for drought tolerance through a more fundamental understanding of underlying mechanisms of drought tolerance and identifying potential candidate genes. These new approaches provide opportunities to direct the continued breeding of genotypes giving stable yields under drought stress.
\end{abstract}

Key words: drought tolerance, marker assisted selection, omics, quantitative trait loci, transgenics.

\section{Introduction}

Cereal crops have been predominantly used as staple food around the globe since the time immemorial. However, our efforts in meeting the food requirements on sustainable basis for ever increasing population are seriously being hampered due to biotic and abiotic stresses. Abiotic factors (like drought, salinity and temperature), are most important accounting for about $70 \%$ reductions in yield of our cereal crops (Boyer, 1982). Drought is a major yield limiting factor badly affecting the crop productivity worldwide (Hussain et al., 2011). The simplest definition of drought in the context of agriculture is a situation when the water availability to plant is less than what is required to sustain its growth and development (Deikman et al., 2011). Drought tolerance is the ability of the plant to survive in water limited conditions (Turner, 1979). However, inducing drought tolerance in crop plants is not a simple task rather one of the most difficult challenges currently the breeders face. This is due to its polygenic nature with low heritability and high $\mathrm{G} \times \mathrm{E}$ interactions (Fleury et al., 2010). This complex nature and also the lack of proper understanding of the underlying mechanisms of drought tolerance explain the slow progress in improving the yield of crops in drought prone environments (Tuberosa, Salvi, 2006; Cattivelli et al., 2008). Plants use different mechanisms to cope with the drought. Like they use the escape strategy through accelerating flowering before the onset of drought season (Deikman et al., 2011), or improve the water use efficiency (WUE) through closing stomata and increasing root development (Gowda et al., 2011) or can also use some tolerance mechanisms such as osmotic adjustment and production of antioxidants (Umezawa et al., 2006), yet there is no unified drought mechanism at the whole plant or gene level (Blum, 2004). This review encompasses an overview on the current work reported in inducing drought tolerance in cereal crops mainly wheat, rice and maize, highlighting the role of conventional breeding in conjunction with marker assisted selection, transgenic approaches and modern genomic tools.

\section{Conventional breeding for drought tolerance}

In the last century, conventional plant breeding, especially the cereal breeding has played a very vital role in tackling the food productivity issues on sustainable level (Araus et al., 2008; Ashraf, 2010). The Green Revolution, occurring between the early 1940s and the late 1970s, was actually based on conventional breeding leading to development of high yielding cereal crops thus saving millions of people from starvation (Rajaram, 2005). The overall plant response to drought stress is quite complex involving the interaction of different component traits (primary and secondary) with the external environment. Most of the drought related cereal breeding programs concentrate on selection strategies of those cultivars that yield well under drought stress. This selection can be either empirical focusing on primary trait selection such as yield or physiological based on secondary parameters (Araus et al., 2008).

The selection based on yield potential has led to development of high yielding cultivars of wheat and maize performing well in drought prone environments (Araus et al., 2002). The role of International Maize and Wheat Improvement Center (CIMMYT), International Rice Research Institute (IRRI) and International Center for Tropical Agriculture (CIAT) has been phenomenal in this regard. Breeders from these institutes selected genotypes yielding in both stress and stress free environments. This resulted in maize yield increase from 59 to $233 \mathrm{~kg} \mathrm{ha}^{-1}$ 
cycle $^{-1}$ (Bänziger et al., 2004 as reviewed by Ashraf, 2010) and similarly under drought conditions, yield gains were also high (146 kg ha-1 year $^{-1}$ ) (Campos et al., 2004). However, the progress through this empirical selection has been slow due to low heritability of yield (Ribaut et al., 1997).

Consequently the yield improvements in drought prone environments can be made through identifying secondary traits involved in drought tolerance. The effectiveness of selection of these secondary traits has been well documented in rice (Manickavelu et al., 2006), wheat (Richards et al., 2000) and in maize (Chapman, Edmeades, 1999). A number of such secondary parameters including anatomical traits (e.g., root characteristics), physiological attributes (e.g., gas exchange, osmotic adjustment), measures of plant water status (e.g., leaf water potential; relative water contents) and cell membrane stability are recognized as important components of drought tolerance in cereals (Jongdee et al., 2002; Toorchi et al., 2003; Steele et al., 2006). The prerequisite requirement for these secondary traits is their high genetic correlation with grain yield, high heritability with low $\mathrm{G} \times \mathrm{E}$ interaction. Secondary traits meeting these criteria will greatly enhance the selection efficiency (Araus et al., 2008). Some of the traits like leaf water potential, senescence (stay green) and osmotic adjustment (OA) have been extensively studied to have strong positive correlation with grain yield (Jongdee et al., 2006; Cattivelli et al., 2008). From the above discussion, it can be inferred that breeders have made excellent strides by improving the crop phenology making it to sustain drought, even then there is a need to use some of the advanced methods of biotechnology for drought tolerance improvements in our cereal crops.

\section{Mapping quantitative trait loci (QTLs) associated with drought tolerance}

Traits which show continuous variation (polygenic) are called quantitative traits while genes behind those traits are simply referred to as QTLs. Mapping is putting genes or QTLs in order indicating relative distances among them assigning them to their linkage groups on the basis of their recombination values (Hussain, 2006). Generally the mapping population is derived from crosses between closely related species differing in the traits in question. There is long standing interest in QTL mapping due to the fact that it will ultimately help us to gain insight into very basic architecture of the trait concerned. Five types of populations are generally employed for QTL mapping. These are double haploids, recombinant inbred lines (RILs), backcross populations, near isogenic lines (NILs) and F2 populations. This QTL mapping allows assessing the locations, numbers, magnitude of phenotypic effects, and pattern of gene action (Vinh, Paterson, 2005). Different recent mapping populations used for QTL analysis for drought tolerance in cereals are described in Table 1.

Table 1. Summary of most recent quantitative trait loci (QTLs) associated with drought tolerance in cereals

\begin{tabular}{|c|c|c|c|c|}
\hline Trait & Cross & Species & $\begin{array}{l}\text { QTL mapping } \\
\text { population }\end{array}$ & References \\
\hline Physio-morphological traits & CT9993 × IR62266 & rice & RILs & Subashri et al., 2009 \\
\hline Physio-morphological and yield traits & IR $20 \times$ Nootripathu & rice & NILs & Gomez et al., 2010 \\
\hline Various morpho-physiological traits & Zhenshan $97 \times$ IRAT 109 & rice & NILs & Ding et al., 2011 \\
\hline Photosynthesis parameters & $\begin{array}{l}\text { Low land rice cv. Shennong } 265 \\
\times \text { Upland rice cv. Haogelao }\end{array}$ & rice & backcross (ILs) & Gu et al., 2012 \\
\hline Various morpho-physiological traits & Durum $\times$ Wild emmer & wheat & RILs & Peleg et al., 2009 \\
\hline $\begin{array}{l}\text { Various productivity and } \\
\text { physiological traits }\end{array}$ & Seri M82 $\times$ Babax & wheat & RILs & $\begin{array}{l}\text { McIntyre et al., 2010, } \\
\text { Suzuky et al., } 2010\end{array}$ \\
\hline Leaf growth and ASI & Ac7643 $\times$ Ac7729/TZSR W & maize & RILs & Welcker et al., 2007 \\
\hline Root traits & CML444 × SC-Malawi & maize & RILs & Trachsel et al., 2009 \\
\hline Root traits and yield & Lo964 × Lo1016 & maize & NILs & Landi et al., 2010 \\
\hline Root traits & Ac7643 $\times$ Ac7729/TZSRW & maize & RILs & Ruta et al., 2010 \\
\hline $\begin{array}{c}\text { Physiological traits associated with } \\
\text { seedling water stress }\end{array}$ & Zong3 $\times 87-1$ & maize & RILs & Liu et al., 2011 \\
\hline $\begin{array}{l}\text { Plant senescence, relative leaf chlorophyll } \\
\text { contents and root capacitance }\end{array}$ & CML444 × SC-Malawi & maize & RILs & Messmer et al., 2011 \\
\hline Stay green & Q319 $\times$ Mo17 & maize & $\mathrm{F} 2$ & Zheng et al., 2009 \\
\hline
\end{tabular}

ASI - anthesis-silking interval; RILs - recombinant inbred lines, NILs - near isogenic lines, ILs - introgression lines

Today unprecedented efforts are being made in dissecting complex traits into their single genetic determinants (QTLs) in order to increase the efficiency of marker assisted selection (MAS) (Gu et al., 2012). An increasing number of QTLs related to drought response have been reported, and these include QTLs for root morphology and other root traits such as root penetration ability (Price et al., 2002; Babu et al., 2003; Uga et al., 2011), osmotic adjustment (Robin et al., 2003), grain yield and yield components (Lafitte et al., 2004; Xu et al., 2005), stay green (Jiang et al., 2004), canopy temperature, leaf rolling and leaf drying (Yue et al., 2006).

Most QTLs for drought tolerance in wheat have been identified through yield and yield component measurements under water-limited conditions (as reviewed by Fleury et al., 2010). However, QTL mapping related to drought stress can be applied to any growth stage from germination to grain filling stage. QTLs corresponding to different morphological and physiological traits in various mapping populations have been identified like growth of shoot and roots (Landjeva et al., 2008); osmotic adjustment (Morgan, Tan, 1996), grain yield (Kirigwi et al., 2007; Salem et al., 2007) and thousand grain weight (Nezhad et al., 2012).

The applications of QTL mapping in the genetic dissection of the drought tolerance in rice are certain to be difficult (Price et al., 2002). However, the current research is on identifying QTLs stable across variable environments and also be able to co-segregate with yield (Witcombe et al., 2008). Babu et al. (2003) used double 
haploids derived from rice lines and subjected them to water stress. The experiment resulted in identification of 47 drought related QTLs. They also identified major QTLs on chromosome 4 with pleiotropic effects on yield under drought stress. Similarly Bernier et al. (2009) mapped a QTL qt112.1 with a large effect on grain yield under drought stress. Sellamuthu et al. (2011) identified a total of 46 QTLs related to reproductive growth traits correlated with yield. The overall phenotypic affects ranged $9.5 \%$ to $35.6 \%$. Recently Vikram et al. (2011) identified a major QTL (qDTY1.1) for grain yield under reproductive stage drought stress on chromosome 1. Roots play a critical role in water and nutrient absorption. Hence a deeper root system is desirable as it contribute to enhanced water uptake during drought stress. A number of root related QTLs have been identified in rice. Steele et al. (2006) mapped a QTL on chromosome 9 involved in root length and thickness. Similarly Obara et al. (2010) mapped a major QTL qRL6.1 for root length, on chromosome 6. Uga et al. (2011) identified a major QTL Dro 1 on chromosome 9 playing a crucial role in deep rooting.

During the last two decades, numerous QTLs related to morpho-physiological and secondary traits like anthesis-silking interval (ASI), leaf rolling, stay green and deeper rooting in maize have been identified showing a strong correlation with yield and displayed increased genetic variability in drought conditions (Nikolic et al., 2011). Lebreton et al. (1995) are given the credit to have first attempted to apply QTL analysis in maize to get genetic insights into the drought tolerance phenomenon. Later Ribaut et al. (1996) identified six putative QTLs for ASI under drought on chromosomes 1, 2, 5, 6, 8 and 10, together accounting for $47 \%$ of the phenotypic variance. Nikolic et al. (2011) identified and mapped 43 QTLs related to yield and other agronomic traits. Earlier Ruta et al. (2010) working on 208 RILs derived from a cross of maize parent varieties Ac7643 (drought tolerant) and Ac7729/TZSRW (drought susceptible), identified 13 root related QTLs. Similarly Jing et al. (2011) identified numerous QTLs related to ASI, plant height, grain yield, ear height and ear setting under drought stress conditions.

In summary, many drought related QTLs have been identified in our major cereal crops that can be effectively used in our breeding programs. This necessitates that more and more replicated yield tests are to be conducted in order to accurately characterize their effects and to evaluate their stability across different environments (Cattivelli et al., 2008). As lack of stability across different environments and QTL $\times \mathrm{E}$ interaction evaluation remains a major impediment towards the efficient use of marker assisted selection (MAS) (Bernier et al., 2008; Cattivelli et al., 2008).

\section{Marker assisted selection (MAS) to improve drought tolerance}

Since drought tolerance characters are quantitative in nature, the complete genetic dissection of these complex traits into component genetic factors is a preliminary task. Therefore molecular genetic markers offer a great opportunity of locating the QTLs controlling these traits (Manickavelu et al., 2006). These molecular markers are very powerful as these remain unaffected by the external environment. Once it is ensured that these markers are tightly linked and tagged with a QTL concerned, selection at early segregating generation can be pursued (Khan, 2012). Thus MAS saves time and valuable resources by eliminating undesirable phenotypic evaluation. With the replacement of 1980s RFLP markers with more advanced polymerase chain reaction (PCR) based markers like simple sequence repeats (SSR) or microsatellites, amplified fragment length polymorphism (AFLP) and random amplified polymorphic DNA (RAPD), the cost effectiveness of MAS is greatly increased as very small amount of template DNA is required to screen large populations (Ghafoor, McPhee, 2012). Earlier Kirigwi et al. (2007) constructed a SSR/EST (expressed sequence tag) marker map to find a grain yield QTL on the proximal region of wheat chromosome 4AL having a significant impact on drought stress performance. Huseynova and Rustamova (2010) successfully used RAPD markers to screen 12 wheat genotypes against drought tolerance.

In maize, MAS was applied to introgress QTLs reducing ASI. Molecular markers were linked with five QTLs related to ASI. The selected lines were superior to the control ones under severe drought stress (Ribaut et al., 2004). Ribaut and Ragot (2007) used marker assisted backcrossing in maize to introgress the alleles at five QTLs for ASI trait. Similarly in rice, Courtois et al. (2003) used MAS to transfer a number of QTLs related to deep rooted character from the japonica upland cultivar 'Azucena' to the lowland indica variety IR64. Steele et al. (2006) used marker assisted backcrossing to transfer five root related QTLs from 'Azucena' to Indian cultivar 'Kalinga III'. Using the SSR markers, Yue et al. (2006) identified a number of QTLs related to yield and root parameters under drought. Bernier et al. (2007) screened $436 \mathrm{~F} 3$ rice lines by adopting the MAS approach and a QTL on chromosome 12 having a marked effect on the yield under drought stress conditions was identified.

Although molecular markers have been successfully associated with QTLs, yet this association has shown limited practicality in cereal breeding (Araus et al., 2008). One of the prerequisites of MAS is the close linkage of DNA marker with the target locus. However, this linkage can be broken by the genetic recombination. Furthermore, the effects of individual QTLs on the phenotype are relatively small. This implies the need to manipulate several (perhaps from three to five) QTLs in the breeding program for significant impact (Araus et al., 2008; Kamoshita et al., 2008). Moreover, there is a possibility that DNA markers developed for a certain genetic background may prove ineffective for others (Gupta et al., 2006). Apart from this there are some cost related issues, inadequate quality of markers and epistatic interactions that need to be addressed before the MAS can successfully be deployed in our breeding programs.

\section{Transgenics}

The identification of candidate genes is critical for our understanding of molecular and physiological mechanisms of drought tolerance in cereals, as it will enable us to use transgenic approaches in breeding for abiotic stress tolerance (Dolferus et al., 2011). A transgenic approach is one that involves some structural modifications in traits through gene transfers from one species to the other (Ashraf, 2010). As the regulatory networks underlying the abiotic stress responses are being fully understood, more and more candidate genes will be identified to be used in development of transgenic plants (Barnabás et al., 2008). A detailed description of drought tolerance genes can be found in the review of Hadiarto and Tran (2011). A number of such genes associated with drought tolerance have been identified. Like transcription factors that upregulate and downregulate the expression of other genes. 
Some of the other identified stress-responsive genes are functional genes which encode metabolic components, such as late embryogenesis abundant (LEA) proteins and osmoprotectant-synthesizing enzymes. (Yang et al., 2010 as reviewed by Hadiarto and Tran, 2011). Most important and well studied class of transcription factors is drought responsive element binding (DREB) factors especially $D R E B 1 A$ and $D R E B 2 A$ identified in Arabidopsis as well as in cereal crops (Hussain et al., 2011). Initial studies with DREB started with Arabidopsis. Over-expression of DREB 1/CBF in Arabidopsis resulted in the activation of expression of many stress-tolerance genes and the tolerance of the plant to abiotic stresses was greatly improved (as reviewed by Gosal et al., 2009). In most of the cases the overexpression of DREB1A is obtained by using constitutive (CaMV 35S) promoter or the dehydration inducible (rd29A) promoter. In transgenic Arabidopsis plants Kasuga et al. (1999) found that overexpression of $C B F 3 / D R E B 1 \mathrm{~A}$ accompanied by constitutive promoter CaMV $35 \mathrm{~S}$ greatly improved plant's tolerance to abiotic stresses including drought stress. Similarly, the use of the stress inducible promoter rd29A in conjunction with DREB1 has been found to enhance drought tolerance in tobacco (Kasuga et al., 2004) and wheat (Pellegrineschi et al., 2004). RD29 genes are induced by desiccation, cold and salt stresses thus endowing plants to tolerate these stresses ( $\mathrm{Jia}$ et al., 2012). A list of some of the recent transgenic lines produced in cereal crops is given in Table 2 .

Table 2. List of transgenic lines produced in cereal crops for drought tolerance

\begin{tabular}{|c|c|c|c|}
\hline Transgene & Crop & Trait improved & Reference \\
\hline HVA1 & rice & $\begin{array}{l}\text { transgenic plants showed improved tolerance } \\
\text { to drought conditions }\end{array}$ & Xiao et al., 2007 \\
\hline HVA1 & wheat & $\begin{array}{l}\text { transgenic plants showed improved tolerance } \\
\text { to drought conditions }\end{array}$ & $\begin{array}{l}\text { Sivamani et al., } \\
2000 \\
\end{array}$ \\
\hline$C B F 3 / D R E B 1 A$ & rice & drought and salinity tolerance & Oh et al., 2005 \\
\hline$S N A C 1$ & rice & $\begin{array}{l}\text { transgenic plants showed improved tolerance } \\
\text { to drought conditions }\end{array}$ & Hu et al., 2006 \\
\hline OsNAC10 & rice & $\begin{array}{c}\text { transgenic plants showed improved grain yield and } \\
\text { tolerance to drought }\end{array}$ & Jeong et al., 2010 \\
\hline Os LEA-3-1 & rice & $\begin{array}{c}\text { transgenic plants showed increased growth } \\
\text { under drought conditions }\end{array}$ & Xiao et al., 2007 \\
\hline $\begin{array}{c}\text { Tomato ethylene response factor (ERF) } \\
\text { protein TSRF1 } \\
\end{array}$ & rice & $\begin{array}{l}\text { TSRF1 improved the osmotic and drought tolerance } \\
\text { of rice seedlings without growth retardation }\end{array}$ & Quan et al., 2010 \\
\hline $\begin{array}{l}\text { Tomato ethylene response factor (ERF) } \\
\text { protein } J E R F 3\end{array}$ & rice & $\begin{array}{c}\text { over expression of } J E R F 3 \text { significantly enhanced } \\
\text { drought tolerance of transgenic rice }\end{array}$ & Zhang et al., 2010 \\
\hline $\begin{array}{l}\text { Sorghum } S b D R E B 2 \text { gene with } \\
\text { stress-induced promoter } \\
\text { CaMV35S or rd29A }\end{array}$ & rice & $\begin{array}{c}\text { over expression of } S B D R E B 2 \text { significantly enhanced } \\
\text { drought tolerance and yield improvement } \\
\text { in transgenic rice }\end{array}$ & Bihani et al., 2011 \\
\hline $\begin{array}{c}\text { Rice } O s D R E B 2 A \text { gene with } \\
\text { stress-inducible promoter rd29A }\end{array}$ & rice & $\begin{array}{l}\text { over expression of } O s D R E B 2 A \text { significantly } \\
\text { enhanced drought and salt tolerance of transgenic rice }\end{array}$ & $\begin{array}{l}\text { Mallikarjuna et al., } \\
2011\end{array}$ \\
\hline Rice OsSDIRl gene & rice & $\begin{array}{c}\text { over expression of OSSDIRI gene significantly } \\
\text { enhanced drought and salt tolerance }\end{array}$ & Gao et al., 2011 \\
\hline$m t l D$ (osmoprotectant) & wheat & $\begin{array}{l}\text { improved fresh and dry weights, plant height, and flag } \\
\text { leaf length in transgenic plants }\end{array}$ & Abebe et al., 2003 \\
\hline Asrl (A putative transcription factors) & maize & $\begin{array}{c}\text { transgenic maize lines showed improved tolerance } \\
\text { to drought }\end{array}$ & $\begin{array}{l}\text { Jeanneau et al., } \\
2002\end{array}$ \\
\hline $\begin{array}{l}Z m N F-Y B 2 \text { (an orthologous maize } \\
\text { transcription factor from the nuclear } \\
\text { factor } Y(N F-Y) \text { family) }\end{array}$ & maize & $\begin{array}{c}\text { transgenic maize lines showed improved tolerance } \\
\text { to drought }\end{array}$ & $\begin{array}{l}\text { Castiglioni et al., } \\
2008\end{array}$ \\
\hline$Z m N F-Y B 2$ & maize & $\begin{array}{c}\text { transgenic maize plants showed } 50 \% \text { increased yield } \\
\text { under drought conditions }\end{array}$ & $\begin{array}{l}\text { Nelson et al., } \\
2007\end{array}$ \\
\hline $\begin{array}{c}\text { OsPFA-DSP1 } \\
\text { (a rice protein tyrosine phosphatase) }\end{array}$ & rice & $\begin{array}{c}\text { transgenic rice and Tobacco plants showed sensitivity } \\
\text { to drought stress }\end{array}$ & Liu et al., 2012 \\
\hline
\end{tabular}

Oh et al. (2005) successfully engineered the rice with transcription factor $C B F 3 / D R E B 1 A$ from Arabidopsis thaliana. Recently Cui et al. (2011) found the overexpression of $O S D R E B 2 A$ significantly enhanced drought and salt tolerance of transgenic rice plants. Overexpression of $\mathrm{ZmDREB2A}$ with $\mathrm{CaMV} 35 \mathrm{~S}$ or rd29A promoters resulted in better tolerance to drought in maize (Qin et al., 2007). Wang et al. (2011) isolated the $Z m D B P 4$ gene, a member of the A-1 subgroup of the $C B F /$ $D R E B$ subfamily, from maize seedlings. They found that overexpression of $\mathrm{ZmDBP} 4$ in transgenic Arabidopsis leads to improved cold and drought tolerance.

In addition to DREB, another class of transcription factors involved in developmental regulation of plants conferring drought tolerance is stress responsive NAC (NAM ATAF and CUC2) family. More than 100 members of this family have been identified but only few of them have been characterized (Hussain et al., 2011). Hu et al. (2006) found that overexpression of NAC encoding rice $S N A C 1$ gene in transgenic rice showed high yield and tolerance to drought. Ethylene responsive factors (ERFs) belong to the large APETALA2 (AP2)/ $E R F$ transcription factor superfamily involved in growth, development and both biotic and abiotic stress responses in plants (Hussain et al., 2011; Li et al., 2011). In a recent study, an overexpression of tomato ERF protein JERF1 in transgenic rice plants resulted in improved tolerance to drought stress (Zhang et al., 2010).

LEA proteins found in the seeds and vegetative parts of plants have been tested to have some association 
with increased stress tolerance in plants (Gosal et al., 2009). Several transgenic rice and wheat plants overexpressing barley LEA gene HVA1 have shown increased tolerance to water deficit conditions (Sivamani et al., 2000; Xiao et al., 2007). Another important class of proteins, known as heat shock proteins (HSPs), generally remains undetectable in the vegetative tissues of plants under normal growth conditions and can be induced when environmental stresses ensue (Bartels, Sunkar, 2005). Sun et al. (2001) found that transgenic Arabidopsis plants overexpressing AtHSP17.7 showed improved tolerance to drought and salinity. Similarly in rice small heat-shock protein encoding $s H S P 17.7$ gene was overexpressed in 'Hoshinoyume' rice variety that resulted in drought tolerant transgenic plants (Sato, Yokoya, 2008). Further strategies used to successfully improve drought tolerance in cereals include the overexpressions of osmoprotectants (Abebe et al., 2003), phosphatases (Xu et al., 2007), and other stress related genes (Shi et al., 2001).

Tremendous progress has been made in the past two decades in developing transgenic lines, helping us to understand and manipulate plant responses to stress. Most of these lines have been tested in the laboratory and many of these recent discoveries are in rice which serves as a model for other cereal crops. The effectiveness of these transgenic lines in enhancing drought tolerance without jeopardizing yield and other related traits under the field conditions needs to be fully assessed.

\section{Use of "omics" technologies for drought tolerance}

The applications of omics type technologies are beginning to have an impact in enhancing our understanding of plant's responses towards external environmental stimuli. The term "omics" is a blend of high throughput genomics, proteomics (analysis of protein complement) and metabolomics approaches. The generation of expressed sequence tags (ESTs) from cDNA libraries and complete genome sequence information in Arabidopsis and rice provide valuable information about gene discovery (Sreenivasulu et al., 2007). Houde et al. (2006) reported that the digital expression analysis of EST sequences combined with gene annotation, resulted in the identification of several pathways associated with abiotic stress tolerance in wheat. With the advancement of DNA microarray technology, several hundred stress induced genes have been identified in plants (Umezawa et al., 2006). cDNA and oligonucleotide microarrays have been widely used in plants, such as Arabidopsis, rice, maize (Vij, Tyagi, 2007). Seki et al. (2001) constructed Arabidopsis full-length cDNA microarrays using about 1300 full-length cDNAs. Forty-four genes were identified as drought inducible. Kawasaki et al. (2001) first reported the use of microarray to study global gene expression profiling in response to abiotic stress in rice. Later Gorantla et al. (2005) used functional genomics and generated a large number of ESTs from cDNA libraries and identified 589 genes involved in drought stress. Wang et al. (2007) compared gene expression between upland and lowland rice cultivars under drought stress using cDNA microarray. Compared with rice, the genomes of other cereals are large and complex (Paterson, 2006). Even then the projects to sequence the genomes of some cereals have been undertaken like in maize (http://www.maizegenome.org/), sorghum (http:// www.jgi.doe.gov/) (Bedell et al., 2005) and wheat (http:// www.wheatgenome.org/) (Varshney et al., 2006). Apart from ESTs, other techniques like serial analysis of gene expression (SAGE), array-based transcript profiling technologies and quantitative real time PCR (qRT-PCR) allow us to assess the high throughput expression of thousands of genes involved in drought tolerance (Sreenivasulu et al., 2007).

Investigating the effects of drought on the protein composition may also provide a clue towards understanding a link between external environmental stress and plant development (Barnabás et al., 2008). Thus proteome analysis is applied to study the alterations in gene expression in relation to drought $(\mathrm{Hu}$ et al., 2010). Salekdeh et al. (2002) working on the proteome analysis identified more than 1000 proteins in rice. Out of these, 42 were differentially expressed in drought stress. Ali and Komatsu (2006) performed a proteomic analysis on rice leaf sheaths and identified a protein actin depolymerizing factor (ADF). The increased level of $\mathrm{ADF}$ in drought tolerant plants suggested that ADF is one of the target proteins induced in drought stress. Recently Yang et al. (2011) performed a proteome analysis of rice roots to identify water deficit responsive proteins among two cultivars IR64 and 'Azucena'. Out of 700 proteins detected, only 15 showed different responses to water stress between two ecotypes.

Similar proteome analysis has also been started in other cereal crops as well. Riccardi et al. (2004) identified 46 proteins in maize leaves. They found an increase in quantity of these proteins in leaves of plants subjected to water stress. Hu et al. (2011) found a differential expression of 22 proteins in maize roots in response to drought stress.

Metabolomics is one of the omics used to acquire comprehensive information about the metabolites in plants (Okazaki, Saito, 2012). The metabolite changes in plants in response to environmental stresses suggest that complete metabolite profiling may provide valuable insights into stress tolerant mechanisms of plants (Langridge et al., 2006). Metabolomics is a relatively new area of research and it is expected that when combined with genomics, transcriptomics and proteomics, it will help us to understand and interpret many complex biological processes (Langridge et al., 2006; Okazaki, Saito, 2012).

From the above discussion, it can be inferred that considerable progress has been made in the field of omics, providing valuable information on the structure and behaviour of crop genomes, with better understanding of plant responses to environmental stresses (Langridge, Fleury, 2011). However, there are challenges and issues that need to be tackled and considered for successful exploitation of the omics technologies. Some of these are regulatory variations, precise phenotying, technical and cost related issues (Varshney et al., 2006).

\section{Conclusion and future prospects}

Considering the importance of cereal crops as a predominant source of food around the world, identification of traits and genotypes associated with drought tolerance is absolutely necessary. Concerted efforts are required to fully understand the physiological and genetic basis of drought tolerance. Focus should be on screening resistant germplasm and discovering potential candidate genes. Characterization and mapping of such genes at the physiological and molecular level will be key factors in the application of molecular marker technology to the development of more drought tolerant cultivars. Transgenic and omics based technologies have been shown to be powerful tools holding a tremendous promise for the future. However, these approaches need 
to be fine-tuned and their significance at the controlled and field conditions need be fully assessed. Surely, the new genomic tools will enhance but not replace the conventional breeding and selection process (Varshney et al., 2005). An interdisciplinary approach combining the knowledge of plant breeders, crop physiologists and molecular biologists would be most appropriate to study and evaluate the complex plant responses to develop drought tolerant cereal crops.

Received 10092012 Accepted 09012013

\section{References}

Abebe T., Guenzi A. C., Martin B., Cushman J. C. 2003. Tolerance of mannitol-accumulating transgenic wheat to water stress and salinity. Plant Physiology, 131: 1748$1755 \mathrm{http}: / / \mathrm{dx}$.doi.org/10.1104/pp.102.003616

Ali G. M., Komatsu S. 2006. Proteomic analysis of rice leaf sheath during drought stress. Journal of Proteome Research, 5 (2): 396-403 http://dx.doi.org/10.1021/pr050291g

Araus J. L., Slafer G. A., Reynolds M. P., Royo C. 2002. Plant breeding and drought in C3 cereals: what should we breed for? Annals of Botany, 89: 925-940 http://dx.doi.org/10.1093/aob/mcf049

Araus J. L., Slafer G. A., Royo C., Serret M. D. 2008. Breeding for yield potential and stress adaptation in cereals. Critical Reviews in Plant Science, 27: 377-412 http://dx.doi.org/10.1080/07352680802467736

Ashraf M. 2010. Inducing drought tolerance in plants: Recent advances. Biotechnology Advances, 28 (1): 169-183 http://dx.doi.org/10.1016/j.biotechadv.2009.11.005

Babu R. C., Nguyen B. D., Chamarerk V., Shanmugasundaram P., Chezhian P., Jeyaprakash P., Ganesh S. K., Palchamy A., Sadasivam S., Sarkarung S., Wade L. J., Nguyen H. T. 2003. Genetic analysis of drought resistance in rice by molecular markers: association between secondary traits and field performance. Crop Science, 43: 1457-1469 http://dx.doi.org/10.2135/cropsci2003.1457

Bänziger M., Setimela P. S., Hodson D., Vivek B. 2004. Breeding for improved drought tolerance in maize adapted to southern Africa. Proceedings of the $4^{\text {th }}$ International Crop Science Congress. Brisbane, Australia

Barnabás B., Jäger K., Fehér A. 2008. The effect of drought and heat stress on reproductive processes in cereals. Plant, Cell and Environment, 31: 11-38

Bartels D., Sunkar R. 2005. Drought and salt tolerance in plants. Critical Reviews in Plant Sciences, 24 (1): 23-58 http://dx.doi.org/10.1080/07352680590910410

Bedell J. A., Budiman M. A., Nunberg A., Citek R. W., Robbins D., Jones J., Flick E., Rohlfing T., Fries J., Bradford K., McMenamy J., Smith M., Holeman H., Roe B. A., Wiley G., Korf I. F., Rabinowicz P. D., Lakey N., McCombie W. R., Jeddeloh J. A., Martienssen R. A. 2005. Sorghum genome sequencing by methylation filtration. PLOS Biology, 3: 103-115 http://dx.doi.org/10.1371/journal.pbio.0030013

Bernier J., Kumar A., Venuprasad R., Spaner D., Atlin G. 2007. A large-effect QTL for grain yield under reproductive-stage drought stress in upland rice. Crop Science, 47: 507-518 http://dx.doi.org/10.2135/cropsci2006.07.0495

Bernier J., Atlin G. N., Serraj R., Kumar A., Spaner D. 2008. Breeding upland rice for drought resistance. Journal of the Science of Food and Agriculture, 88 (6): 927-939 http://dx.doi.org/10.1002/jsfa.3153

Bernier J., Serraj R., Kumar A., Venuprasad R. Impa S., Gowda R. P. V., Oane R., Spaner D., Atlin G. 2009. The largeeffect drought-resistance QTL qt112.1 increases water uptake in upland rice. Field Crops Research, 110 (2): 139 146 http://dx.doi.org/10.1016/j.fer.2008.07.010
Bihani P., Char B., Bhargava S. 2011. Transgenic expression of sorghum DREB2 in rice improves tolerance and yield under water limitation. Journal of Agricultural Science, 149: 95$101 \mathrm{http}: / /$ dx.doi.org/10.1017/S0021859610000742

Blum A. 2004. The physiological foundation of crop breeding for stress environments. Proceedings of the World Rice Research Conference. Tsukuba, Japan, p. 456-458

Boyer J. S. 1982. Plant productivity and environment. Science, 218: 443-448 http://dx.doi.org/10.1126/science.218.4571.443

Campos H., Cooper M., Habben J. E., Edmeades G. O., Schussler J. R. 2004. Improving drought tolerance in maize: a view from industry. Field Crops Research, 90: 19-34 http://dx.doi.org/10.1016/j.fcr.2004.07.003

Castiglioni P.,Warner D., Bensen R. J., Anstrom D. C., Harrison J., Stoecker M., Abad M., Kumar G., Salvador S., D’Ordine R., Navarro S., Back S., Fernandes M., Targolli J., Dasgupta S., Bonin C., Luethy M. H., Heard J. E. 2008. Bacterial RNA chaperones confer abiotic stress tolerance in plants and improved grain yield in maize under waterlimited conditions. Plant Physiology, 147: 446-455 http://dx.doi.org/10.1104/pp.108.118828

Cattivelli L., Rizza F., Badeck F. W., Mazzucotelli E., Mastrangelo A. M., Francia E., Mare C., Tondelli A., Stanca A. M. 2008. Drought tolerance improvement in crop plants: an integrative view from breeding to genomics. Field Crop Research, 105: 1-14 http://dx.doi.org/10.1016/j.fcr.2007.07.004

Chapman S. C., Edmeades G. O. 1999. Selection improves drought tolerance in tropical maize populations. II. Direct and correlated responses among secondary traits. Crop Science, 39: 1315-1324 http://dx.doi.org/10.2135/cropsci1999.3951315x

Courtois B., Shen L., Petalcorin W., Carandang S., Mauleon R., Li Z. 2003. Locating QTLs controlling constitutive root traits in the rice population IAC $165 \times$ Co39. Euphytica, 134: $335-345$

http://dx.doi.org/10.1023/B:EUPH.0000004987.88718.d6

Cui M., Zhang W., Zhang Q., Xu Z., Zhu Z., Duan F., Wub R. 2011. Induced over-expression of the transcription factor OsDREB2A improves drought tolerance in rice. Plant Physiology and Biochemistry, 49: 1384-1391 http://dx.doi.org/10.1016/j.plaphy.2011.09.012

Deikman J., Petracek M., Heard J. E. 2011. Drought tolerance through biotechnology: improving translation from the laboratory to farmers' fields. Current Opinion in Biotechnology, 23: 1-8

Ding X., Li X., Xiong L. 2011. Evaluation of near-isogenic lines for drought resistance QTL and fine mapping of a locus affecting flag leaf width, spikelet number, and root volume in rice. Theoretical and Applied Genetics, 123: 815-826 http://dx.doi.org/10.1007/s00122-011-1629-1

Dolferus R., Ji X., Richards R. A. 2011. Abiotic stress and control of grain number in cereals. Plant Science, 181: 331-341 http://dx.doi.org/10.1016/j.plantsci.2011.05.015

Fleury D., Stephen J. S., Kuchel H., Langridge P. 2010. Genetic and genomic tools to improve drought tolerance in wheat. Journal of Experimental Botany. 61 (12): 3199-3210 http://dx.doi.org/10.1093/jxb/erq152

Gao T., Wu Y., Zhang Y., Liu L. Ning Y., Wang D., Tong H., Chen S., Chu C., Xie Q. 2011. OsSDIR1 overexpression greatly improves drought tolerance in transgenic rice. Plant Molecular Biology, 76: 145-156 http://dx.doi.org/10.1007/s11103-011-9775-z

Ghafoor A., McPhee K. 2012. Marker assisted selection (MAS) for developing powdery mildew resistant pea cultivars. Euphytica, 186: 593-607 http://dx.doi.org/10.1007/s10681-011-0596-6

Gomez S. M, Boopathi M. N., Kuman S. S., Ramasubramanian T., Chengsong Z., Jeyaprakash P., Senthil A., Babu C. R. 2010. Molecular mapping and location of QTLs for 
drought-resistance traits in indica rice (Oryza sativa L.) lines adapted to target environments. Acta Physiologiae Plantarum, 32 (2): 355-364

http://dx.doi.org/10.1007/s11738-009-0413-1

Gorantla M., Babu P. R., Lachagari V. B. R., Feltus F. A., Paterson A. H., Reddy A. R. 2005. Functional genomics of drought stress response in rice: transcript mapping of annotated unigenes of an indica rice (Oryza sativa L. cv. Nagina 22). Current Science, 89 (3): 496-514

Gosal S. S., Wani S. H., Kang M. S. 2009. Biotechnology and drought tolerance. Journal of Crop Improvement, 23: 1954 http://dx.doi.org/10.1080/15427520802418251

Gowda V. R. P., Henry A., Yamauchi A., Shashidhar H. E., Serraj R. 2011. Root biology and genetic improvement for drought avoidance in rice. Field Crops Research, 122: 1-13 http://dx.doi.org/10.1016/j.fcr.2011.03.001

Gu J., Yin X., Struik P. C., Stomph T. J., Wang H. 2012. Using chromosome introgression lines to map quantitative trait loci for photosynthesis parameters in rice (Oryza sativa L.) leaves under drought and well-watered field conditions. Journal of Experimental Botany. 63 (1): 455-469 http://dx.doi.org/10.1093/jxb/err292

Gupta S. K., Charpe A., Koul S., Haque Q. M. R., Prabhu K. V. 2006. Development and validation of SCAR markers cosegregating with an Agropyron elongatum derived leaf rust resistance gene Lr24 in wheat. Euphytica. 150: 233-240 http://dx.doi.org/10.1007/s10681-006-9113-8

Hadiarto T., Tran L. S. P. 2011. Progress studies of droughtresponsive genes in rice. Plant Cell Reports. 30: 297-310 http://dx.doi.org/10.1007/s00299-010-0956-z

Houde M., Belcaid M., Ouellet F., Danyluk J., Monroy A. F., Dryanova A., Gulick P., Bergeron A., Laroche A., Links M. G., MacCarthy L., Crosby W. L., Sarhan F. 2006. Wheat EST resources for functional genomics of abiotic stress. BMC Genomics, 7: 149 http://dx.doi.org/10.1186/1471-2164-7-149

Hu H., Dai M., Yao J., Xiao B., Li X., Zhang Q., Xiong L. 2006. Overexpressing a NAM, ATAF, and CUC (NAC) transcription factor enhances drought resistance and salt tolerance in rice. Proceedings of the National Academy of Sciences of the USA, 103 (35): 12987-12992 http://dx.doi.org/10.1073/pnas.0604882103

Hu X., Li Y., Li C., Yang H., Wang W., Lu M. 2010. Characterization of small heat shock proteins associated with maize tolerance to combined drought and heat stress. Journal of Plant Growth Regulation, 29: 455-464 http://dx.doi.org/10.1007/s00344-010-9157-9

Hu X., Lu M., Li C., Liu T., Wang W., Wu J., Tai F., Li X., Zhang J. 2011. Differential expression of proteins in maize roots in response to abscisic acid and drought. Acta Physiologiae Plantarum, 33: 2437-2446 http://dx.doi.org/10.1007/s11738-011-0784-y

Huseynova I. M., Rustamova S. M. 2010. Screening for drought stress tolerance in wheat genotypes using molecular markers. Proceedings of ANAS (Biological Sciences), 65 (5-6): 132-139

Hussain S. S. 2006. Molecular breeding for abiotic stress tolerance: drought perspective. Proceedings of the Pakistan Academy of Sciences, 43 (3): 189-210

Hussain S. S., Kayani M. A., Amjad M. 2011. Transcription factors as tools to engineer enhanced drought stress tolerance in plants. Biotechnology Progress, 27 (2): 297306 http://dx.doi.org/10.1002/btpr.514

Jeanneau M., Gerentes D., Foueillassar X., Zivy M., Vidal J., Toppan A., Perez P. 2002. Improvement of drought tolerance in maize: towards the functional validation of the $\mathrm{Zm}$-Asrl gene and increase of water use efficiency by over-expressing C4-PEPC. Biochimie, 84: 1127-1135 http://dx.doi.org/10.1016/S0300-9084(02)00024-X

Jeong J. S., Kim Y. S., Baek K. H., Jung H., Ha S. H., Choi Y. D., Kim M., Reuzeau C., Kim J. K. 2010. Root-specific expression of OsNAC10 improves drought tolerance and grain yield in rice under field drought conditions. Plant Physiology, 153: 185-197 http://dx.doi.org/10.1104/pp.110.154773

Jia H., Zhang S., Ruan M., Wang Y., Wang C. 2012. Analysis and application of RD29 genes in abiotic stress response. Acta Physiologiae Plantarum. 34: 1239-1250 http://dx.doi.org/10.1007/s11738-012-0969-z

Jiang G. H., He Y. Q., Xu C. G., Li X., Zhang Q. 2004. The genetic basis of stay-green in rice analysed in a population of doubled haploid lines derived from an indica by japonica cross. Theoretical and Applied Genetics. 108: 688-698 http://dx.doi.org/10.1007/s00122-003-1465-Z

Jing Z. J., Peng W. X., Xia S. C., Miao Z. X., Meng L., Dong Z. G., Chen T. Y., Li W. Z. 2011. Mapping of QTL associated with drought tolerance in a semi-automobile rain shelter in maize (Zea mays L.). Agricultural Sciences in China, 10 (7): 987-996 http://dx.doi.org/10.1016/S1671-2927(11)60085-0

Jongdee B., Fukai S., Cooper M. 2002. Leaf water potential and osmotic adjustment as physiological traits to improve drought tolerance in rice. Field Crops Research, 76: 153163 http://dx.doi.org/10.1016/S0378-4290(02)00036-9

Jongdee B., Pantuwan G., Fukai S. Fischer K. 2006. Improving drought tolerance in rainfed lowland rice: an example from Thailand. Agriculture Water Management, 80: 225-240 http://dx.doi.org/10.1016/j.agwat.2005.07.015

Kamoshita A., Babu R. C., Boopathi N. M., Fukai S. 2008. Phenotypic and genotypic analysis of drought-resistance traits for development of rice cultivars adapted to rainfed environments. Field Crops Research. 109: 1-23 http://dx.doi.org/10.1016/j.fcr.2008.06.010

Kasuga M., Liu Q., Miura S., Yamaguchi-Shinozaki K., Shinozaki K. 1999. Improving plant drought, salt and freezing tolerance by gene transfer of a single stressinducible transcription factor. Nature Biotechnology, 17: 287-291 http://dx.doi.org/10.1038/7036

Kasuga M., Miura S., Shinozaki K., Yamaguchi-Shinozaki K. 2004. A combination of the Arabidopsis DREB1A gene and stress-inducible rd29A promoter improved droughtand low-temperature stress tolerance in tobacco by gene transfer. Plant and Cell Physiology, 45: 346-350 http://dx.doi.org/10.1093/pcp/pch037

Kawasaki S., Borchert C., Deyholos M., Wang H., Brazille S., Kawai K., Galbraith D., Bohnert H. J. 2001. Gene expression profiles during the initial phase of salt stress in rice. The Plant Cell, 13: 889-905

Khan M. A. 2012. Current status of genomic based approaches to enhance drought tolerance in rice (Oryza sativa L.), an over view. Molecular Plant Breeding, 3 (1): 1-10 http://dx.doi.org/10.5376/mpb.2012.03.0001

Kirigwi F. M., Van Ginkel M., Brown-Guedira G., Gill B. S., Paulsen G. M., Fritz A. K. 2007. Markers associated with a QTL for grain yield in wheat under drought. Molecular Breeding. 20: 401-413 http://dx.doi.org/10.1007/s11032-007-9100-3

Lafitte H. R., Price A. H., Courtois B. 2004. Yield response to water deficit in an upland rice mapping population: associations among traits and genetic markers. Theoretical and Applied Genetics. 109: 1237-1246 http://dx.doi.org/10.1007/s00122-004-1731-8

Landi P., Giuliani S., Salvi S., Ferri M., Tuberosa R., Sanguineti M. C. 2010. Characterization of root-yield-1.06, a major constitutive QTL for root and agronomic traits in maize across water regimes. Journal of Experimental Botany, 61: 3553-3562 http://dx.doi.org/10.1093/jxb/erq192

Landjeva S., Neumann K., Lohwasser U., Borner A. 2008. Molecular mapping of genomic regions associated with wheat seedling growth under osmotic stress. Biologia Plantarum, 52: 259-266 http://dx.doi.org/10.1007/s10535-008-0056-x

Langridge P., Fleury D. 2011. Making the most of 'omics' for crop breeding. Trends in Biotechnology, 29: 33-40 http://dx.doi.org/10.1016/j.tibtech.2010.09.006 
Langridge P., Paltridge N., Fincher G. 2006. Functional genomics of abiotic stress tolerance in cereals. Briefings of Functional Genomics and Proteomics, 4: 343-354 http://dx.doi.org/10.1093/bfgp/eli005

Lebreton C., Laziejancie V., Steed A., Pekic S., Quarrie S. A. 1995. Identification of QTL for drought responses in maize and their testing casual relationships between traits. Journal of Experimental Botany, 46: 853-865 $\mathrm{http} / / / \mathrm{dx}$. doi.org/10.1093/jxb/46.7.853

Li J., Zhang Y., Gu J., Guo C., Wen S., Liu G., Xiao K. 2011. Molecular characterization and roles of AP2 transcription factors on drought tolerance in plants. Frontiers of Agriculture in China. 5 (4): 463-472 http://dx.doi.org/10.1007/s11703-011-1148-5

Liu B., Fan J., Zhang Y., Mu P., Wang P., Su J., Lai H., Li S., Feng D., Wang J., Wang H. 2012. OsPFA-DSP1, a rice protein tyrosine phosphatase, negatively regulates drought stress responses in transgenic tobacco and rice plants. Plant Cell Reports, 31 (6): 1021-1032 http://dx.doi.org/10.1007/s00299-011-1220-x

Liu Y., Subhash C., Yan J., Song C., Zhao J., Li J. 2011. Maize leaf temperature responses to drought: Thermal imaging and quantitative trait loci (QTL) mapping. Environmental and Experimental Botany, 71: 158-165 http://dx.doi.org/10.1016/j.envexpbot.2010.11.010

Mallikarjuna G., Mallikarjuna K., Reddy M. K., Kaul T. 2011. Expression of OsDREB2A transcription factor confers enhanced dehydration and salt stress tolerance in rice (Oryza sativa L.). Biotechnology Letters. 33: 1689-1697 http://dx.doi.org/10.1007/s10529-011-0620-x

Manickavelu A., Nadarajan N., Ganesh S. K., Gnanamalar R. P., Babu R. C. 2006. Drought tolerance in rice: morphological and molecular genetic consideration. Plant Growth Regulation. 50: 121-138 http://dx.doi.org/10.1007/s10725-006-9109-3

McIntyre C. L., Mathews K. L., Rattey A., Chapman S. C., Drenth J., Ghaderi M., Reynolds M., Shorter R. 2010. Molecular detection of genomic regions associated with grain yield and yield-related components in an elite bread wheat cross evaluated under irrigated and rainfed conditions. Theoretical and Applied Genetics, 120: 527$541 \mathrm{http}: / /$ dx.doi.org/10.1007/s00122-009-1173-4

Messmer R., Fracheboud Y., Bänziger M., Stamp P., Ribaut J. M. 2011. Drought stress and tropical maize: QTLs for leaf greenness, plant senescence, and root capacitance. Field Crops Research, 124: 93-103 http://dx.doi.org/10.1016/j.fcr.2011.06.010

Morgan J. M., Tan M. K. 1996. Chromosomal location of a wheat osmoregulation gene using RFLP analysis. Australian Journal of Plant Physiology, 23: 803-806 http://dx.doi.org/10.1071/PP9960803

Nelson D. E., Repetti P. P., Adams T. R., Creelman R. A., Wu J., Warner D. C., Anstrom D. C., Bensen R. J., Castiglioni P. P., Donnarummo M. G., Hinchey B. S., Kumimoto R. W., Maszle D. R., Canales R. D., Krolikowski K. A., Doston S. B., Gutterson N., Ratcliffe O. J., Heard J. E. 2007. Plant nuclear factor Y (NF-Y) B subunits confer drought tolerance and lead to improved corn yields on water-limited acres. Proceedings of the National Academy of Sciences of the USA, 104: 16450-16455 http://dx.doi.org/10.1073/pnas.0707193104

Nezhad K.Z., WeberW.E., Roder M. S., Sharma S., Lohwasser U., Meyer R. C., Saal B., Borner A. 2012. QTL analysis for thousand-grain weight under terminal drought stress in bread wheat (Triticum aestivum L.). Euphytica, 186 (1): 127-138 http://dx.doi.org/10.1007/s10681-011-0559-y

Nikolic A., Andjelkovic V., Dodig D., Ignjatovic-Micic D. 2011. Quantitative trait loci for yield and morphological traits in maize under drought stress. Genetika. 43 (2): 263 $276 \mathrm{http} / / / \mathrm{dx}$.doi.org/10.2298/GENSR1102263N

Obara M., Tamura W., Ebitani T., Yano M., Sato T., Yamaya T. 2010. Fine-mapping of qRL6.1, a major QTL for root length of rice seedlings grown under a wide range of NH4 + concentrations in hydroponic conditions. Theoretical and Applied Genetics, 121 (3): 535-547

http://dx.doi.org/10.1007/s00122-010-1328-3

Oh S. J., Song S. I., Kim Y. S., Jang H. J., Kim S. Y., Kim M. 2005. Arabidopsis CBF3/DREB1 A and ABF3 in transgenic rice increased tolerance to abiotic stress without stunting growth. Plant Physiology, 138: 341-351 http://dx.doi.org/10.1104/pp.104.059147

Okazaki Y., Saito K. 2012. Recent advances of metabolomics in plant biotechnology. Plant Biotechnology Reporter, 6: $1-15$ http://dx.doi.org/10.1007/s11816-011-0191-2

Paterson A. H. 2006. Leafing through genomes of our major crop plants: strategies for capturing unique information. Nature Reviews. Genetics, 7: 174-184 http://dx.doi.org/10.1038/nrg1806

Peleg Z., Fahima T., Krugman T., Abbo S., Yakir D., Korol A. B., Saranga Y. 2009. Genomic dissection of drought resistance in durum wheat $\times$ wild emmer wheat recombinant inbreed line population. Plant. Cell and Environment. 32: 758-779 http://dx.doi.org/10.1111/j.1365-3040.2009.01956.x

Pellegrineschi A., Reynolds M., Pacheco M., Brito R. M., Almeraya R., Yamaguchi-Shinozaki K., Hoisington D. 2004. Stress-induced expression in wheat of the Arabidopsis thaliana DREB1A gene delays water stress symptoms under greenhouse conditions. Genome, 47: 493-500 http://dx.doi.org/10.1139/g03-140

Price A. H., Cairns J. E., Horton P., Jones H. G., Griffiths H. 2002. Linking drought-resistance mechanisms to drought avoidance in upland rice using a QTL approach: progress and new opportunities to integrate stomatal and mesophyll responses. Journal of Experimental Botany, 53: 989-1004 http://dx.doi.org/10.1093/jexbot/53.371.989

Qin F., Kakimoto M., Sakuma Y., Maruyama K., Osakabe Y., Tran L. S. P., Shinozaki K., Yamaguchi S. K. 2007. Regulation and functional analysis of $Z m D R E B 2 A$ in response to drought and heat stress in Zea mays L. The Plant Journal, 50: 54-69 http://dx.doi.org/10.1111/j.1365-313X.2007.03034.x

Quan R., Hu S., Zhang Z., Zhang H., Zhang Z. Huang R. 2010. Overexpression of an ERF transcription factor TSRF1 improves rice drought tolerance. Plant Biotechnology Journal, 8: 476-488 http://dx.doi.org/10.1111/j.1467-7652.2009.00492.x

Rajaram S. 2005. Role of conventional plant breeding and biotechnology in future wheat production. Turkish Journal of Agriculture and Forestry, 29: 105-111

Ribaut J. M., Hoisington D. A., Deutsch J. A., Jiang C., Gonzalez-de-Leon D. 1996. Identification of quantitative trait loci under drought conditions in tropical maize. 1. Flowering parameters and the anthesis-silking interval. Theoretical and Applied Genetics. 92: 905-914 http://dx.doi.org/10.1007/BF00221905

Ribaut J. M., Jiang C., Gonzalez-de-Leon D., Edmeades G. O., Hoisington D. A. 1997. Identification of quantitative trait loci under drought conditions in tropical maize. 2. Yield components and marker-assisted selection strategies. Theoretical and Applied Genetics, 94: 887-896 http://dx.doi.org/10.1007/s001220050492

Ribaut J. M., Hoisington D., Banziger M., SetterT., Edmeades G. 2004. Genetic dissection of drought tolerance in maize: a case study. Physiology and Biotechnology Integration for Plant Breeding Nguyen H. T., Blum A. (eds). New York, USA, p. 571-609

Ribaut J. M., Ragot M. 2007. Marker-assisted selection to improve drought adaptation in maize: the backcross approach, perspectives, limitations, and alternatives. Journal of Experimental Botany. 58: 351-360 http://dx.doi.org/10.1093/jxb/erl214

Riccardi F., Gazeau P., Jacquemot M. P., Vincent D., Zivy M. 2004. Deciphering genetic variations of proteome 
responses to water deficit in maize leaves. Plant Physiology and Biochemistry. 42: 1003-1011

http://dx.doi.org/10.1016/j.plaphy.2004.09.009

Richards R. A., Rebetzke G. J., Appels R., Condon A. G. 2000 Physiological traits to improve the yield of rain-fed wheat: can molecular genetics help? Ribaut J. M., Poland D. (eds). Molecular approaches for the genetic improvement of cereals for stable production in waterlimited environments: a strategic planning workshop. CIMMYT, El Batan, Mexico, p. 54-58

Robin S., Pathan M. S., Courtois B., Lafitte R., Carandang S., Lanceras S., Amante M., Nguyen H. T., Li Z. 2003. Mapping osmotic adjustment in an advanced backcross inbred population of rice. Theoretical and Applied Genetics, 107: 1288-1296 http://dx.doi.org/10.1007/s00122-003-1360-7

Ruta N., Liedgens M., Fracheboud Y., Stamp P., Hund A. 2010. QTLs for the elongation of axile and lateral roots of maize in response to low water potential. Theoretical and Applied Genetics, 120: 621-631 h http://dx.doi.org/10.1007/s00122-009-1180-5

Salekdeh G. H., Siopongco J., Wade L. J., Ghareyazie B., Bennett J. 2002. A proteomic approach to analyzing drought- and saltresponsiveness in rice. Field Crops Research, 76: 199-219 http://dx.doi.org/10.1016/S0378-4290(02)00040-0

Salem K. F. M., Roder M. S., Borner A. 2007. Identification and mapping quantitative trait loci for stem reserve mobilization in wheat (Triticum aestivum L.). Cereal Research Communications. 35: 1367-1374 http://dx.doi.org/10.1556/CRC.35.2007.3.1

Sato Y., Yokoya S. 2008. Enhanced tolerance to drought stress in transgenic rice plants overexpressing a small heat-shock protein, sHSP17.7. Plant Cell Reports, 27: 329-334 http://dx.doi.org/10.1007/s00299-007-0470-0

Seki M., Narusaka M., Abe H., Kasuga M., YamaguchiShinozaki K., Carninic P., Hayashizaki Y., Shinozaki K. 2001. Monitoring the expression pattern of 1300 Arabidopsis genes under drought and cold stresses by using a full-length cDNA microarray. The Plant Cell, 13: $61-72$

Sellamuthu R., Liu G. F., Ranganathan C. B., Serraj R. 2011. Genetic analysis and validation of quantitative trait loci associated with reproductive-growth traits and grain yield under drought stress in a doubled haploid line population of rice (Orvza sativa L.). Field Crops Research, 124: 46$58 \mathrm{http} / / / \mathrm{dx}$.doi.org/10.1016/j.fcr.2011.06.002

Shi W. M., Muramoto Y., Ueda A., Takabe T. 2001. Cloning of peroxisomal ascorbate peroxidase gene from barley and enhanced thermotolerance by overexpressing in Arabidopsis thaliana. Gene. 273: 23-27 http://dx.doi.org/10.1016/S0378-1119(01)00566-2

Sivamani E., Bahieldin A., Wraith J., Al-Niemi T., Dyer W., Ho T., Qu R. 2000. Improved biomass productivity and water use efficiency under water deficit conditions in transgenic wheat constitutively expressing the barley HVA1 gene. Plant Science, 155: 1-9 http://dx.doi.org/10.1016/S0168-9452(99)00247-2

Sreenivasulu N., Sopory S. K., Kavi Kishor P. B. 2007. Deciphering the regulatory mechanisms of abiotic stress tolerance in plants by genomic approaches. Gene, 388: 1-13 http://dx.doi.org/10.1016/j.gene.2006.10.009

Steele K. A., Price A. H, Shashidar H. E., Witcombe J. R. 2006. Marker-assisted selection to introgress rice QTLs controlling root traits into an Indian upland rice variety. Theoretical and Applied Genetics, 12: 208-221 http://dx.doi.org/10.1007/s00122-005-0110-4

Subashri M., Robin S., Vinod K. K., Rajeswari S. Mohanasundaram K., Raveendran T. S. 2009. Trait identification and QTL validation for reproductive stage drought resistance in rice using selective genotyping of near flowering RILs. Euphytica, 166: 291-305 http://dx.doi.org/10.1007/s10681-008-9847-6
Sun W., Bernard C., van de Cotte B., van Montagu M., Verbruggen N. 2001. At-HSP17.6A, encoding a small heatshock protein in Arabidopsis, can enhance osmotolerance upon overexpression. The Plant Journal, 27 (5): 407-415 http://dx.doi.org/10.1046/j.1365-313X.2001.01107.x

Suzuky P. R., Reynolds M. P., Mathews K. Y. L., McIntyre C. L., Olivares-Villegas J.-J., Chapman S. C. 2010. Heat and drought adaptive QTL in a wheat population designed to minimize confounding agronomic effects. Theoretical and Applied Genetics, 121: 1001-1021 http://dx.doi.org/10.1007/s00122-010-1351-4

Toorchi M., Shashidhar H. E., Gireesha T. M., Hittalmani S. 2003. Performance of backcross involving trangressant doubled haploid lines in rice under contrasting moisture regimes: yield components and marker heterozygosity. Crop Science, 43: 1448-1456 http://dx.doi.org/10.2135/cropsci2003.1448

Trachsel S., Messmer R., Stamp P., Hund A. 2009. Mapping of QTLs for lateral and axile root growth of tropical maize. Theoretical and Applied Genetics, 119: 1413-1424 http://dx.doi.org/10.1007/s00122-009-1144-9

Tuberosa R., Salvi S. 2006. Genomics-based approaches to improve drought tolerance of crops. Trends in Plant Science, 11 (8): 405-412 http://dx.doi.org/10.1016/j.tplants.2006.06.003

Turner N. C. 1979. Drought resistance and adaptation to water deficits in crop plants. Mussell H., Staples C. R. (eds). Stress physiology in crop plants. New York, USA, p. 343-372

Uga Y., Okuno K., Yano M. 2011. Dro1, a major QTL involved in deep rooting of rice under upland field conditions. Journal of Experimental Botany, 62 (8): 2485-2494 http://dx.doi.org/10.1093/jxb/erq429

Umezawa T., Fujita M., Fujita Y., Yamaguchi-Shinozaki K., Shinozaki K. 2006. Engineering drought tolerance in plants discovering and tailoring genes to unlock the future. Current Opinion in Biotechnology, 17: 113-122 http://dx.doi.org/10.1016/j.copbio.2006.02.002

Varshney R. K., Graner A., Sorrells M. E. 2005. Genomicsassisted breeding for crop improvement. Trends in Plant Science, 10 (12): 621-630 http://dx.doi.org/10.1016/j.tplants.2005.10.004

Varshney R. K., Hoisington D. A., Tyag A. K. 2006. Advances in cereal genomics and applications in crop breeding. Trends in Biotechnology, 24 (11): 490-499 http://dx.doi.org/10.1016/j.tibtech.2006.08.006

Vij S., Tyagi A. K. 2007. Emerging trends in the functional genomics of the abiotic stress response in crop plants. Plant Biotechnology Journal. 5: 361-380 http://dx.doi.org/10.1111/j.1467-7652.2007.00239.x

Vikram P., Swamy B. P. M., Dixit S., Ahmed H. U., Cruz M. T. S., Singh A. K., Kumar A. 2011. qDTY1.1, a major QTL for rice grain yield under reproductive-stage drought stress with a consistent effect in multiple elite genetic backgrounds. BMC Genetics, 12: 89-105 http://dx.doi.org/10.1186/1471-2156-12-89

Vinh N. T., Paterson A. H. 2005. Genome mapping and its implication for stress resistance in plants. Ashraf M., Harris P. J. C. (eds). Abiotic stresses: plant resistance through breeding and molecular approaches. Lucknow, India, p. 109-124

Wang C. T., Yang Q., Yang Y. M. 2011. Characterization of the ZmDBP4 gene encoding a CRT/DRE-binding protein responsive to drought and cold stress in maize. Acta Physiologiae Plantarum, 33: 575-583 http://dx.doi.org/10.1007/s11738-010-0582-y

Wang H., Zhang H., Gao F., Li J., Li Z. 2007. Comparison of gene expression between upland and lowland rice cultivars under water stress using cDNA microarray. Theoretical and Applied Genetics. 115: 1109-1126 http://dx.doi.org/10.1007/s00122-007-0637-7 
Welcker C., Boussuge B., Bencivenni C., Ribaut J. M., Tardieu F. 2007. Are source and sink strengths genetically linked in maize plants subjected to water deficit? A QTL study of the responses of leaf growth and of Anthesis-Silking Interval to water deficit. Journal of Experimental Botany, 58 (2): 339-349 http://dx.doi.org/10.1093/jxb/erl227

Witcombe J. R., Hollington P. A., Howarth C. J., Reader S., Steele K. A. 2008. Breeding for abiotic stresses for sustainable agriculture. Philosophical Transactions of the Royal Society of London, Series B: Biological Sciences, 363 (1492): 703-716 http://dx.doi.org/10.1098/rstb.2007.2179

Xiao B., Huang Y., Tang N., Xiong L. 2007. Over-expression of a LEA gene in rice improves drought resistance under the field conditions. Theoretical and Applied Genetics, 115: 35-46 http://dx.doi.org/10.1007/s00122-007-0538-9

Xu C., Jing R., Mao X., Jia X., Chang X. 2007. A wheat (Triticum aestivum) protein phosphatase 2 a catalytic subunit gene provides enhanced drought tolerance in tobacco. Annals of Botany, 99: 439-450 http://dx.doi.org/10.1093/aob/mcl285

Xu J. L., Lafitte H. R., Gao Y. M., Fu B. Y., Torres R., Li Z. K. 2005. QTLs for drought escape and tolerance identified in a set of random introgression lines of rice. Theoretical and
Applied Genetics, 111: 1642-1650

http://dx.doi.org/10.1007/s00122-005-0099-8

Yang L., Su N., Wu M., Wang C., Hu H. 2011. Proteomics to identify pathogenesis-related proteins in rice roots under water deficit. Biologia, 66: 477-483 http://dx.doi.org/10.2478/s11756-011-0054-X

Yang S., Vanderbeld B., Wan J., Huang Y. 2010. Narrowing down the targets: towards successful genetic engineering of drought tolerant crops. Molecular Plant, 3: 469-490

Yue B., Xue W., Xiong L., Yu X., Luo L., Cui K., Lin D., Xing Y., Zhang Q. 2006. Genetic basis of drought resistance at reproductive stage in rice: separation of drought tolerance from drought avoidance. Genetics, 172: 1213-1228 http://dx.doi.org/10.1534/genetics.105.045062

Zhang Z., Li F., Li D., Zhang H., Huang R. 2010. Expression of ethylene response factor JERF1 in rice improves tolerance to drought. Planta. 232 (3): 765-774 http://dx.doi.org/10.1007/s00425-010-1208-8

Zheng J., Wu A. Z., Zheng C. C., Wang Y. F., Cai R., Shen X. F., Xu R. R., Liu P., Kong L. J., Dong S. T. 2009. QTL mapping of maize (Zea mays) stay-green traits and their relationship to vield. Plant Breeding. 128: 54-62 http://dx.doi.org/10.1111/j.1439-0523.2008.01529.x

ISSN 1392-3196 / e-ISSN 2335-8947

Zemdirbyste-Agriculture, vol. 100, No. 3 (2013), p. 325-334

DOI $10.13080 / \mathrm{z}-\mathrm{a} .2013 .100 .042$

\title{
Nauji pasiekimai kuriant molekulinius ịrankius sausrai atsparių javų selekcijai: apžvalga
}

\author{
M. A. Khan, M. Iqbal, M. Akram, M. Ahmad, W. Hassan, M. Jamil \\ Bahawalpur Islamia universiteto Žemès ūkio ir aplinkos mokslų koledžas, Pakistanas
}

\section{Santrauka}

Sausros sukeltas stresas yra vienas iš javų derlių ribojančių veiksnių. Kuriant sausrai atsparias veisles, tradiciškai taikoma tiesioginè arba netiesiogine atranka. Nors tai veiksmingas metodas, tačiau jis yra imlus laikui ir darbui. Kiekybinių požymių lokusų, susijusių su sausra, identifikavimas kartu su žymekliais pagrịsta atranka jau davė teigiamų rezultatų. Atsparumo sausrai selekcijoje taikomos pažangios transgeninès ir ominès technologijos, leidžiančios geriau suprasti pagrindinius atsparumo sausrai mechanizmus ir nustatyti potencialius genus kandidatus. Šie metodai suteikia galimybę selekciją nukreipti ị genotipų, sausros sukelto streso sąlygomis duodančių stabilų derlių, kūrimą.

Reikšminiai žodžiai: atsparumas sausrai, kiekybinių požymių lokusai, omika, transgenika, žymekliais pagrịsta atranka. 